\title{
White grubs (Cyclocephala flavipennis) damaging perennial winter pastures in the South Region of Brazil
}

\author{
Paulo Gonçalves Duchini ${ }^{1 *}$ Joilson Roda Echeverria $^{1}$ Luana Fidelis Américo $^{1}$ \\ Gabriela Cristina Guzatti ${ }^{1}$ Mariana Alejandra Cherman ${ }^{2}$ André Fischer Sbrissia ${ }^{1}$
}

${ }^{1}$ Programa de Pós-graduação em Ciência Animal, Universidade do Estado de Santa Catarina (Udesc), Avenida Luís de Camões, 2090, 88530-000, Lages, SC, Brasil. E-mail: duchini_p_g@hotmail.com. *Corresponding author.

${ }^{2}$ Laboratório de Sistemática e Bioecologia de Coleoptera, Departamento de Zoologia, Universidade Federal do Paraná (UFPR), Curitiba, PR, Brasil.

\begin{abstract}
Cyclocephala flavipennis Arrow, 1914 (Coleoptera: Melolonthidae), popularly known as white grub, is an insect widely disseminated in the South Region of Brazil. Despite the frequent occurrence of this white grub in areas cultivated with winter cereals, it is generally not considered a pest, since it feeds on straw and dead plant material. However, in 2015 and 2016, this insect has been identified as the damage-causing agent in the perennial winter pastures in Lages, Santa Catarina, Brazil. Damage was observed in patches and caused reduction in root depth and mass, resulting in loss of vigor, accelerated senescence in aerial parts, and death of tillers in Festuca arundinacea Schreb. and Dactylis glomerata L. plants.
\end{abstract}

Key words: damage, Dynastinae, grass, pest, Santa Catarina.

Ocorrência do coró-pequeno (Cyclocephala flavipennis) danificando pastagens perenes de inverno na região Sul do Brasil

RESUMO: Cyclocephala flavipennis Arrow, 1914 (Coleoptera: Melolonthidae), conhecido popularmente como coró-pequeno, é um inseto amplamente disseminado na região sul do Brasil. Embora seja encontrado com frequência em áreas cultivadas com cereais de inverno não é considerado inseto praga, por alimentar-se preferencialmente de palha e restos de plantas. Entretanto, nos anos de 2015 e 2016 foi identificado como causador de danos em pastagens perenes de inverno em Lages, Santa Catarina, Brasil. Os danos foram observados em reboleiras e promoveram redução na massa e profundidade de raizes, resultando em perda de vigor, senescência acelerada da parte aérea e morte de perfilhos de plantas de Festuca arundinacea Schreb. e Dacytilis glomerata L.

Palavras-chave: dano, Dynastinae, gramineas, praga, Santa Catarina.

In the South Region of Brazil, besides the traditional cultivation of winter-annual pastures, cultivation of winter perennial grasses, particularly tall fescue (Festuca arundinacea Schreb.) and orchardgrass (Dactylis glomerata L.), can be an alternative to reduce the periods of low forage production from native and cultivated perennial warm season grasses. Despite the growing relevance of pasture cultivation in the temperate climate regions, little is known about the soil insects causing pasture damage in these areas. In Brazil, 1,008 species of melolontids (Coleoptera: Melolonthidae) have been reported. The larvae of these species live in the soil, and are commonly called "white grubs" (MORÓN, 2004). Among these species, Diloboderus abderus Sturm, 1826, is the main damage-causing agent of the winter cereal crops and pastures, and is geographically distributed in the South of Brazil, Uruguay, and Argentina (GASSEN, 2001; SALVADORI \& OLIVEIRA, 2001; SILVA \& BOSS, 2002; SILVA \& SALVADORI, 2004).

According to CHERMAN et al. (2013), in the plateau of Rio Grande do Sul, a region extending to the border of Santa Catarina, dwells another species together with D. abderus, that is widely disseminated in both cultivated and noncultivated areas: Cyclocephala flavipennis Arrow, 1914. Cyclocephala flavipennis presents an annual cycle, reaching its adult phase during spring. The larvae of this species present a yellowish-white body and legs, light brown head, and might reach approximately $25 \mathrm{~mm}$ in length. The adult presents a 
dark brown head, yellowish-brown body and elytron, and measures approximately $12 \mathrm{~mm}$ in length and 7 $\mathrm{mm}$ in width (PEREIRA \& SALVADORI, 2006).

Although C. Alavipennis is considered a facultative saprophyte because it preferentially consumes decomposing organic matter, straw, and plant residue (GASSEN, 1989; SALVADORI \& PEREIRA, 2006), recently it has been reported to cause damage in the blueberry (Vaccinium ashei Reade) plantations (DIEZRODRÍGUEZ et al., 2015). However, SALVADORI (1999) observed no significant damage caused by $C$. flavipennis in the winter cereal crops with infestations of up to 80 larvae $\mathrm{m}^{-2}$, despite, in the laboratory, $C$. flavipennis consumed roots and damaged wheat plants (SALVADORI \& OLIVEIRA, 2001).

In 2015 and 2016, severe damage was observed in the winter perennial pastures comprising tall fescue and orchardgrass in Lages, SC (27 $47^{\prime}$ $35^{\prime \prime} \mathrm{S}, 50^{\circ} 18^{\prime} 08^{\prime \prime} \mathrm{W}, 960 \mathrm{~m}$ ), with intense reduction in the quantity of roots and increase in the mortality of plants, and this observation was simultaneous to the presence of white grubs. This research aimed to record the larvae of melolontids species present in this pasture area and the damage caused to tall fescue and orchardgrass.

The soil of the area was classified as Inceptisol (Cambisolo Húmico Alumínico típico, EMBRAPA, 2013), and was covered by the native vegetation previously to the plantation of tall fescue and orchardgrass. In May 2013, a chemical analysis of the soil at the depth of $0-20 \mathrm{~cm}$ presented the following values: $\mathrm{pH}_{\mathrm{H} 2 \mathrm{O}}=4.5$; clay $=52 \%$; organic matter $=2.1 \%$; phosphorus $=3.65 \mathrm{mg}$ $\mathrm{dm}^{-3}$; and potassium $=48 \mathrm{mg} \mathrm{dm}^{-3}$. Pastures were planted in June 2013 via broadcast seeding, and whenever plants reached the height of $20 \mathrm{~cm}$ they were trimmed to $10 \mathrm{~cm}$ using a trimmer, followed by removal of the cutted plant material. Fertilization correction and maintenance of winter perennial pastures (Comissão de Química e Fertilidade do Solo - RS/SC, 2004) were performed annually. Maize and wheat crops were planted in the areas adjacent to pastures.

Occurrence of the first damage was observed in March 2015. The damage comprised reduced development and death of tillers and plants in patches, resulting in a lower productivity of pastures than expected and extremely long intervals between cuts. During this period, no incidence of disease was observed in the roots or aerial parts, but close observation of some plants revealed the presence of white grubs, identified as $C$. flavipennis based on the morphological characteristics of the larvae described by PEREIRA \& SALVADORI (2006). However, since the literature does not describe this species as a damage-causing agent of winter cereals $\left(\mathrm{C}_{3}\right.$ grasses $)$ in field conditions, and owing to the fact that pastures recovered on June 2015, the hypothesis that the damage could have been caused by white grubs was discarded.

However, in March 2016, the damage reappeared and coincided with a new infestation of white grubs (Figure 1A, B, C, D). During that period, 15 trenches $(0.50 \times 0.25 \times 0.20 \mathrm{~m})$ were dug at the locations of plant damage in order to quantify the larval density in that area (SALVADORI \& PEREIRA, 2006). Identification of material was performed in the "Laboratório de sistemática e bioecologia de Coleoptera" (UFPR) by Dr. Mariana Alejandra Cherman by consulting bibliography and comparing it with the preserved material (PEREIRA \& SALVADORI, 2006; CHERMAN et al., 2013), which was then deposited in the entomological collection of the laboratory. The populational density of C. flavipennis in that area was 41.6 larvae $\mathrm{m}^{-2}$. Additionally, other species were also reported in the area: Cyclocephala tucumana Brèthes, 1904 (7.5 larvae $\left.\mathrm{m}^{-2}\right)$; Geniates sp. (3.2 larvae $\left.\mathrm{m}^{-2}\right)$; and Macrodactylus sp. (1.1 larvae $\left.\mathrm{m}^{-2}\right)$. Among the Cyclocephala species commonly reported in the South of Brazil (CHERMAN et al., 2013), there are only reports of the damage caused by the larvae of $C$. modesta Burmeister, 1855, due to their high ability to adapt to cropping systems (CHERMAN et al., 2014). In addition, although the other two genera reported are relatively common in the cultivated and noncultivated areas of the plateau of Rio Grande do Sul, there are no records of damage caused by their larvae (CHERMAN et al., 2014). It should be noted that $D$. abderus larvae were not reported in this area.

Although the populational density of $C$. flavipennis larvae reported in this area is considered insufficient to cause damage to crops (SALVADORI, 1999), the adaptation processes might cause problems (SALVADORI et al., 2008). According to MORÓN (2001), the facultative species might change their strategy of feeding according to the available resources. Therefore, despite C. flavipennis is considered a facultative saprophyte, some specific conditions might have contributed to the preference of this species in feeding from roots, such as low amount of straw and organic matter in the soil, and to the possible preference to particular plant species such as the ones under study. Another factor that might have contributed to the occurrence of damage is the coincidence between the third-instar C. flavipennis larvae (a phase of maximum development in which the melolontids larvae increase their food consumption; GASSEN, 1989; OLIVEIRA et al., 1992), and the season of the year in which tall fescue 


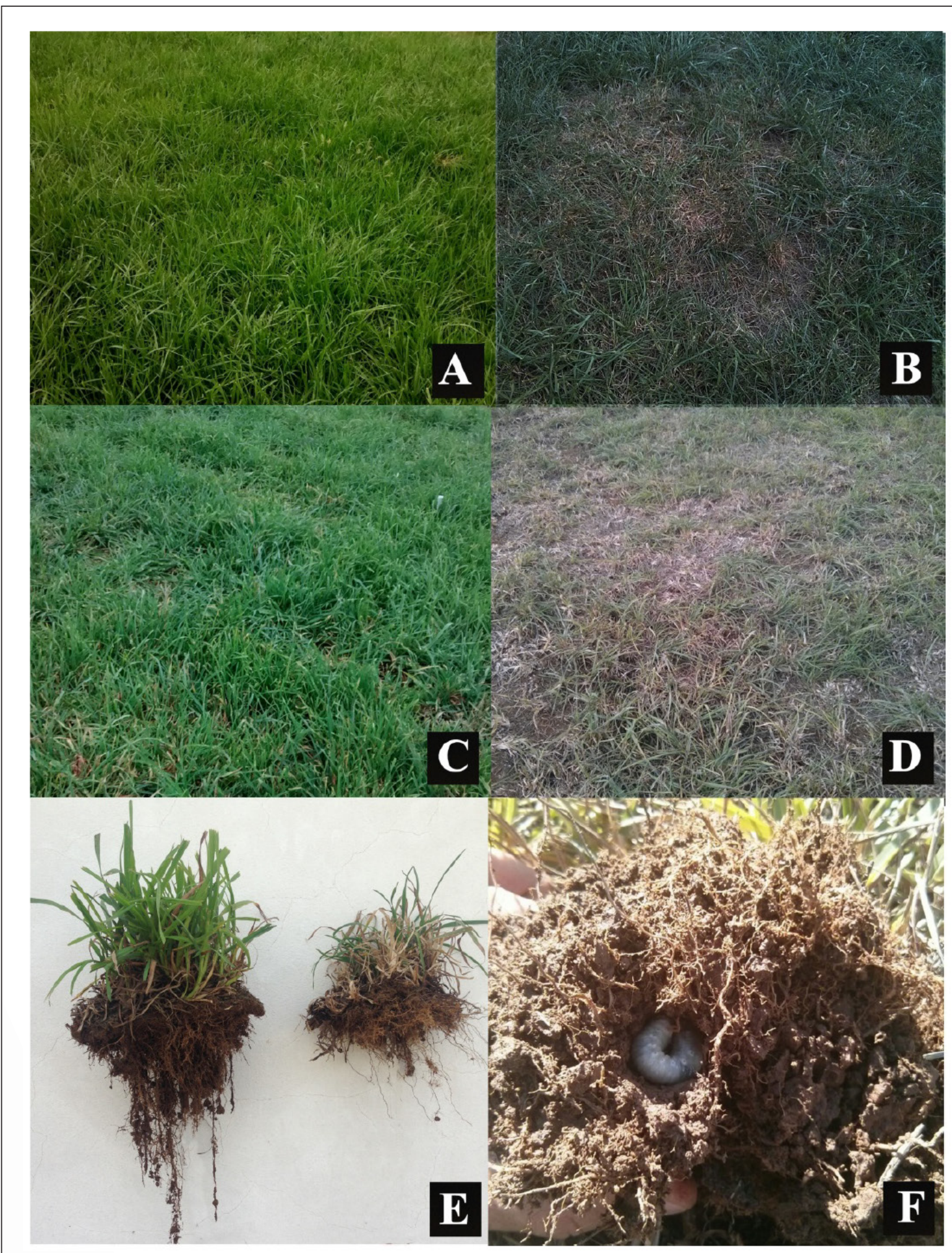

Figure 1 - Pastures of healthy Festuca arundinacea and Dactylis glomerata (A and C, respectively) and with attack from Cyclocephala flavipennis (B and D, respectively). The left plant is healthy and the right plant presents damage to the root system and aerial parts (E). Cyclocephala flavipennis attack near the plant collar (F). 
and orchardgrass present relatively lower amounts of tillers, and low tillering capacity (data not published), making the tillers replenishment difficult and reducing the forage production ability of these pastures.

The main damage observed in the roots was the reduction in their mass and depth (Figure 1E), in addition to small holes near the plant collar where, in many cases, C. flavipennis were reported (Figure 1F). In the aerial parts of the plants, loss of vigor was observed firstly, followed by accelerated senescence, including expanding leaves, resulting in the death of tillers and plants in patches. After the attack period (March to June), the pastures showed gradual recovery with intense tillering.

This is the first report of the occurrence of damage in grasses caused by $C$. flavipennis at field conditions in Brazil, providing a basis for the future studies that aim to improve the understanding of $C$. flavipennis bioecology and management in cultivated pastures or other plants.

\section{AKNOWLEDGEMENTS}

The authors would like to acknowledge Coordenação de Aperfeiçoamento de Pessoal de Nível Superior/ Fundação de Apoio a Pesquisa Científica e Tecnológica do Estado de Santa Catarina (CAPES/FAPESC) for awarding scholarships to the first four authors, and to the Conselho Nacional de Desenvolvimento Científico e Tecnológico (CNPq) for the financial support (process 456394/2014-1).

\section{REFERENCES}

CHERMAN, M. A. et al. White grubs (Coleoptera, Melolonthidae) in the "Planalto Region", Rio Grande do Sul state, Brazil: key for identification, species richness and distribution. Revista Brasileira de Entomologia, v.57, n.3, p.271-278, 2013. Available from: $<$ http://www.scielo.br/pdf/rbent/v57n3/a05v57n3.pdf>. Accessed: May 20, 2016. doi: 10.1590/S0085-56262013000300005.

CHERMAN, M. A. et al. Ecological characterization of White grubs (Coleoptera: Melolonthidae) community in cultivaded and noncultivaded fields. Neotropical Entomology, v.43, n.3, p.282-288, 2014. Available from: <http://link.springer.com/ article/10.1007/s13744-014-0214-0>. Accessed: Oct. 03, 2016. doi: 10.1007/S13744-014-0214-0.

COMISSÃO DE QUÍMICA E FERTILIDADE DO SOLO - RS/SC. Manual de adubação e calagem para os Estados de Rio Grande do Sul e Santa Catarina. 10.ed. Porto Alegre, 2004. 400p.

DIEZ-RODRÍGUEZ, I. G. et al. Record of Cyclocephala flavipennis Arrow, 1914 (Coleoptera: Melolonthidae) injuring blueberry plants in Brazil. Ciência Rural, v.45, n.2, p.189-191, 2015. Available from: <http://www.scielo.br/pdf/cr/v45n2/01038478-cr-45-02-00189.pdf>. Accessed: May 16, 2016. doi: $10.1590 / 0103-8478 \mathrm{cr} 20140412$.

EMBRAPA. Sistema brasileiro de classificação de solos. 3.ed. Brasília: Embrapa produção de informação: Rio de Janeiro,
Embrapa Solos, 2013. 353p.

GASSEN, D. N. Insetos subterrâneos prejudiciais à culturas no sul do Brasil. Passo Fundo: EMBRAPA-CNPT, 1989. 49p. (EMPRAPA-CNPT. Documentos, 13).

GASSEN, D. N. Manejo de Diloboderus abderus em lavouras e pastagens. In: ROSELLO, R. D. Siembra directa em el cono sur. Montevideu, Uruguay: Procisur, 2001. p.173-182.

MORÓN, M. A. Larvas de escarabajos del suelo en México (Coleoptera: Melolonthidae). Acta Zoológica Mexicana, v.1, p.111-130, 2001. Available from: <http://www.redalyc.org/ pdf/575/57500007.pdf $>$. Accessed: Oct. 03, 2016.

MORÓN, M. A. Melolontídeos edafícolas. In: SALVADORI, J. R. et al. Pragas de solo no Brasil. Passo Fundo: Embrapa Trigo; Dourados: Embrapa Agropecuária Oeste; Cruz Alta: Fundacep Fecotrigo, 2004. p.133-166.

OLIVEIRA, L. J. et al. Coró pequeno da soja. Londrina: EMBRAPA - CNPSo, 1992. 4p. (Documentos, 51). Available from: <https://www.infoteca.cnptia.embrapa.br/bitstream/ doc/445533/1/51.pdf $>$. Accessed: Oct. 05, 2016.

PEREIRA, P. R. V. S; SALVADORI, J. R. Guia para identificação de corós rizófagos (Coleoptera: Scarabaeoidea: Melolonthidae) comumente encontrado em cereais de inverno, milho e soja no norte do Rio Grande do Sul. Passo Fundo. Embrapa Trigo, 2006. 8p. (Comunicado técnico online 204). Available from: <http://www.cnpt.embrapa.br/biblio/co/p_ co204.pdf>. Accessed: Sept. 30, 2016.

SALVADORI, J. R. Efeito de níveis de infestação do coró Cyclocephala flavipennis em trigo. In: REUNIÃO NACIONAL DE PESQUISA DE TRIGO, 18., 1999, Passo Fundo, RS. Anais... Passo Fundo: Embrapa Trigo, 1999. V.2, p.570572. Available from: <http://ainfo.cnptia.embrapa.br/digital/ bitstream/item/129190/1/ID13536-XVIIIrenapet-p570-572.pdf>. Accessed: Sept. 30, 2016.

SALVADORI, J. R.; OLIVEIRA, L. J. Manejo de corós em lavouras sob plantio direto. Passo Fundo. Embrapa Trigo, 2001. 88p. (Documentos, 35).

SALVADORI, J. R. et al. Ocorrência e importância dos corós em plantas de lavoura. In: CONGRESSO BRASILEIRO DE ENTOMOlOGIA, 22., 2008, Uberlândia, MG. Anais... Sete Lagoas: Embrapa Milho e Sorgo, 2008. Available from: <http:// seb.web2130.uni5.net/asp/eventos/CBE/XXIICBE/resumos/ R2506-2.html>. Accessed: Sept. 30, 2016.

SALVADORI, J. R.; PEREIRA, P. R. V. S. Manejo integrado de corós em trigo e culturas associadas. Passo Fundo. Embrapa Trigo, 2006. 9p. (Comunicado técnico online 203). Available from: $<$ http://www.cnpt.embrapa.br/biblio/co/p_co203.htm>. Accessed: Mar. 14, 2016

SILVA, M. T. B.; BOSS, A. Controle de larvas de Diloboderus abderus com inseticidas em trigo. Ciência Rural. v.32, n.2, p.191195, 2002. Available from: <http://www.scielo.br/pdf/cr/v32n2/ a02v32n2.pdf>. Accessed: Apr. 15, 2016. doi: 10.1590/S010384782002000200002 .

SILVA, M. T. B.; SALVADORI, J. R. Coró-das-pastagens. In: SALVADORI, J. R. et al. (Eds.). Pragas de solo no Brasil. Passo Fundo: Embrapa Trigo. Dourados: Embrapa Agropecuária Oeste. 